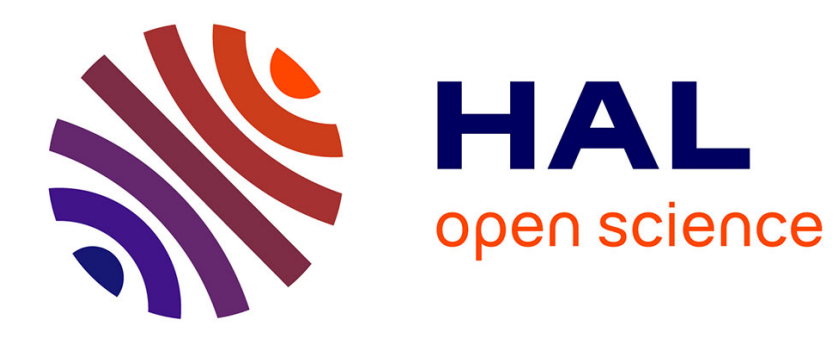

\title{
Re-inventing the Limited Liability Company
}

Bob Tricker

\section{To cite this version:}

Bob Tricker. Re-inventing the Limited Liability Company. Corporate Governance: An International Review, 2011, 19 (4), pp.384. 10.1111/j.1467-8683.2011.00851.x . hal-00631693

\section{HAL Id: hal-00631693 https://hal.science/hal-00631693}

Submitted on 13 Oct 2011

HAL is a multi-disciplinary open access archive for the deposit and dissemination of scientific research documents, whether they are published or not. The documents may come from teaching and research institutions in France or abroad, or from public or private research centers.
L'archive ouverte pluridisciplinaire HAL, est destinée au dépôt et à la diffusion de documents scientifiques de niveau recherche, publiés ou non, émanant des établissements d'enseignement et de recherche français ou étrangers, des laboratoires publics ou privés. 


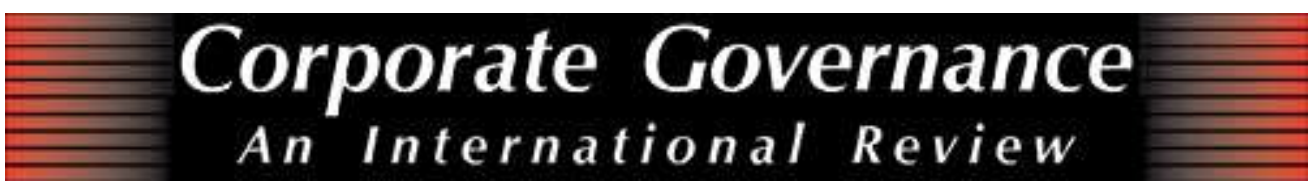

\section{Re-inventing the Limited Liability Company}

\begin{tabular}{|r|l|}
\hline Journal: & Corporate Governance: An International Review \\
\hline Manuscript ID: & CGIR-2010-0296.R3 \\
\hline Manuscript Type: & Perspective \\
\hline Keywords: & $\begin{array}{l}\text { Civil law system < Legal Control Mechanisms, Common law system } \\
\text { < Legal Control Mechanisms, Management Board < Board of } \\
\text { Director Mechanisms }\end{array}$ \\
\hline \multicolumn{2}{|l}{} \\
\hline
\end{tabular}

\section{SCHOLARONE ${ }^{m}$ \\ Manuscripts}




\section{RE-INVENTING THE LIMITED LIABILITY COMPANY}

\section{Manuscript Type Perspective}

Research issue/Question: The evolution of corporate governance thinking and its implications for theory building. The 19th century concept of the corporation still underpins corporate governance practice today: if the company was re-invented to meet contemporary circumstances, what might it look like today?

Research Insights/Findings: The original corporate concept was superbly simple and brilliantly successful. Subsequently, the growing diversity of corporate objectives, confused ownership structures, and complex corporate groups, has led to abuse. Society has lost the control which it originally demanded for the right to incorporate companies in which shareholders' had no liability for corporate debts beyond their equity stake. Faced with government bail-outs of failing companies, allegedly excessive executive remuneration, and a growing concern for corporate social responsibility and sustainability, the time has come to rethink the rationale, the purpose and the governance of the joint-stock, limited-liability company.

Theoretical/Academic implications: This paper has been written in response to the editor's initiative to seek contributions that might provide alternative theoretical insights into corporate governance issues. By taking an historical, evolutionary perspective, this paper looks at corporate governance through a different lens than those of agency theory, stewardship theory or the growing philosophical interest in corporate social responsibility.

The primary theoretical call is for a taxonomy of corporate entities that differentiates them according to the way that power is exercised over them. The paper highlights three unresolved paradoxes in corporate governance orthodoxy: governance by 
principles or rules, independent directors' ignorance of the business, and the unitary board's dual responsibility for both performance and conformance.

Practitioner/Policy implications: The paper offers an alternative paradigm for the governance of corporate entities introducing the concepts of the Governing Body, the Executive Management and Stakeholder Liaison Groups. It is also suggested that external auditors should report to regulators not directors. The underlying argument is that limited liability is a privilege granted by society not a right: what society grants, society can take away if it is not satisfied with the way companies are managed or governed.

Keywords: limited liability, corporate taxonomy, evolution of corporate governance, auditors' responsibilities, Governing Body, Stakeholder Liaison Groups. 


\section{RE-INVENTING THE LIMITED LIABILITY COMPANY}

\section{INTRODUCTION}

The invention of the limited liability company in the mid-nineteenth century led to the formation of vast amounts of capital, the generation of countless jobs, and the creation of incredible worldwide wealth over the years. However, the creators of the original idea recognized that limiting the liability of shareholders for companies' debts was a significant concession by society. So companies' powers were strictly restricted. The objectives of each company had to be precise, bounded, and clearly stated. Company promoters, directors, officers and shareholders had to be declared, and public annual reports and returns were required. The directors' accounts were audited by shareholders' audit committees.

But today, the original concept has become debased. International groups of companies operate through vast pyramids of subsidiary and associated companies, some enjoying the secrecy of haven jurisdictions. Others operate through complex networks of cross-holdings and joint ventures. Some use chains of public companies to leverage the financial advantage of those at the head of the chain. Companies' memoranda of association now provide multiple objectives; indeed some jurisdictions do not require declared objectives at all. The reporting of public, listed companies has become vastly complicated. Compensation consultants and remuneration committees gear-up top executive remuneration. Auditors are effectively appointed by and report to the directors. And corporate regulators constantly battle to stay ahead of schemes devised by companies' lawyers and accountants to circumvent disclosure and tax rules. 
But society is no longer satisfied. Criticisms include complaints of greed and excessive director rewards, erosion of shareholder value, the abuse of power by directors, and corporate failures culminating in the need for governments to bail out companies. The growing interest in corporate social responsibility reflects societies' unease with the potential power of corporate entities and companies' response.

The purpose of this paper is not to propose curbs on board-level powers or to call for further regulation and the strengthening of governance codes. Rather, it reviews the way the original concept of the corporation has evolved and changed, which leads to a call for the re-invention of the corporate concept relevant to contemporary circumstances. The theoretical stance is that of the historian or evolutionary theorist, rather than of the lawyer or financial economist.

The potential contribution of this paper towards a general theory of corporate governance is a call for taxonomy by corporate types, with species and sub-species differentiated by their governance attributes; in other words by the way that power is or could be exercised over them. The paper also offers an alternative corporate governance paradigm introducing concepts of the Governing Body, the Executive Management and Stakeholder Liaison Groups in lieu of the classical processes and structures. The alternative model would shift power back towards shareholders and could reduce alleged excesses, including top management remuneration, and increase shareholder value. It is also argued that external auditors should report to the regulators not the directors.

Overall, this paper calls for scholars, regulators and practitioners to re-invent the limited-liability company. Such re-thinking would need to be backed by legislation and, of course, would meet enormous resistance from the corporate sector supported by the lobbying power of interested parties using shareholder funds to protect their 
vested interests. But the overall argument of this paper is simple: limited liability is a privilege granted by society, it is not an automatic legal right. What society gives society can take away. Unless companies meet societies' expectations, investors should again become liable for their companies' debts.

\section{The theoretical orientation of this paper}

As Pettigrew (1992 pages 163-182) wrote:

"Corporate governance lacks any form of coherence, either empirically, methodologically or theoretically with only piecemeal attempts to try and understand and explain how the modern corporation is run."

Nearly twenty years later, authorities still call for reliable global governance theory (Carver, 2010, Judge, 2010). Stewardship theory lies at the heart of corporate governance, taking a legal perspective of the corporation, emphasising directors' fiduciary duty, acting in the best interests of the shareholders as stewards of their funds. The theory is rooted in the original belief that directors of limited companies can be trusted (Barney and Hesterly, 2008). The stewardship view is central to company law. Indeed, some authorities have raised the possibility of the convergence of corporate governance principles towards a global standard (Coffee, 1999).

Agency theory takes an alternative view: directors are agents of the shareholders but will maximize their own personal utility to the detriment of shareholders' interests (Jensen and Meckling, 1976, Jensen, 2000). Anecdotal evidence is not hard to find. This theoretical construct, with its statistic relevance, has dominated corporate governance research to date, and has been the methodology adopted in the majority of papers published in this journal.

More recently, stakeholder theorists have questioned the legal duty of directors to act solely on behalf of the shareholders, and called on companies to recognize a duty 
to act in the interests of other stakeholders potentially affected by their actions

(McWilliams and Siegal, 2001). Since this theory calls for the rethinking of the rights, responsibilities and roles of companies is society, it might more appropriately be called stakeholder philosophy.

In an endeavour to throw fresh light on the subject, this paper takes a different perspective. Tracing the historical development of corporate governance thinking, practice, and regulation over time it provides an alternative theoretical insight. Such an evolutionary approach reflects the suggestion of Dawkins (1976) that culturallydetermined ideas are transmitted from person to person. Dawkins suggested that the development of ideas is analogous to the natural selection, replication, and mutation of physical genes. He coined the word 'memes' to cover such transferrable ideas. Successful ideas propagate and spread, poor ones become extinct. So it is with corporate governance, this paper argues.

In methodological terms, the paper adopts a process approach (Pettigre, 1979 and 1997, Langley, 1999). In other words, theory is developed from an understanding of how situations come to be constituted, reproduced and adapted as ongoing processes (Langley, 2007). As Pettigrew (1997 pages 337-348) explains the 'processual' approach enables the exploration of:

..."human conduct and organizational life and to embed such dynamics over time in the various layers of context in which streams of activity occur."

Adopting this process and evolutionary approach, this paper traces the development of corporate governance ideas, practices and regulation longitudinally and situationally, then identifies current frontiers and posits further possible developments.

THE EVOLUTION OF CORPRATE GOVERNANCE 


\section{The early stages - merchants and monopolists}

The word 'governance' has a long pedigree. Chaucer (c1343-1400) used it, though he could not decide how it should be spelt. Wilson (1976) wrote of the governance of Britain, and scholars such as Carver $(1981,1984)$ addressed the governance of cities, public agencies, and non-profit organizations. But although the phrase 'corporate governance' did not appear until the 1980s, the agency issue has long been recognized. Shakespeare (1596) understood corporate governance, though he did not use the phrase. Antonio, his Merchant of Venice, agonized as his ships sailed out of sight, the success of the venture and his fortune entrusted to others.

During the 17 and 18th centuries, the growing European empires - Holland, Portugal, Spain, and increasingly England - competed both economically and militarily around the world. Frequently the state or the crown gave charters to companies to trade with those empires. Royalty, members of the aristocracy and rich merchants often invested. Again, they were faced with the agency problem, not least because of slow communications.

In 1600, England's Queen Elizabeth 1 granted a royal charter to the "Governor and Company of Merchants of London" to trade with the East Indies" giving the Honourable East India Company a monopoly over trade between England and Asia. The East India Company was a joint-stock company, with over 1,000 stock-holders who elected a governing body of 24 directors annually. The company was a powerful force for nearly three centuries, trading with India and China in cotton, silk, tea and opium. At one time the company administered parts of the British Indian Empire and ran a private army.

In 1602 the Republic of the Netherlands granted a charter to the Dutch East India Company to colonize and trade with Asia. The Dutch West India Company was 
chartered a year later to run slaves from Africa to the Caribbean and North America. Both companies were joint-stock companies, issuing stock to their investing stock holders. Predictably, the success of corporate ventures allied with poor corporate governance led to unrealistic expectations and subsequent corporate collapses, sometimes associated with fraud. In 1606, England's James 1 established the Virginia Company by royal charter to establish colonial settlements in North America. The Hudson Bay Company was created by Royal Charter in 1670.

In 1720 the British House of Lords gave a monopoly to the South Sea Company to trade with Spain's South American colonies. Unbelievably, the company agreed to underwrite the British national debt, which led to massive speculation in its stock. Then the bubble burst. Many of the investors lost their fortunes, the directors were arrested, and their wealth confiscated.

Just as today, voices were raised against such corporate excesses and risks. Adam Smith $(1759,1776)$, a moral philosopher at the University of Glasgow considered by many to be the father of modern economics, argued that society benefitted as individuals pursued their own self-interest, because the free market then produced the goods and services needed at low prices. But, like many academics today, he was suspicious of businessmen. His well known comment offers a classic corporate governance perspective:

"The directors of such companies, however, being the managers rather of other people's money than their own, it cannot well be expected that they should watch over it with the same anxious vigilance with which the partners in a co-partnery frequently watch over their own... Negligence and profusion, therefore, must always prevail, more or less, in the management of the affairs of such a company."

(Smith, Adam, 1776, An Inquiry into The Wealth of Nations, Book V, page 439) 
In the $18^{\text {th }}$ century, colonist communities in North America suspected exploitation by England and English companies. So when the states declared independence, creating the United States of America in 1776, they tended to be suspicious of corporate power. State legislators viewed the incorporation of a joint-stock company as a privilege and imposed strict conditions on the granting of charters that allowed companies to exist. The business activities of the company had to be clearly defined. Charters were set for specific terms, not perpetuity. Companies could not own stock in other companies. A company's right to operate could be terminated if it exceeded the terms of its charter. American legislators were also wary of limiting the liability of shareholders for their companies' debts.

\section{The mid-19th century - the limited-liability company is invented}

At the start of the 19th century the only way for individuals to invest in business was as a sole-trader, in a partnership, or as a shareholder in a joint-stock company. If a business failed its creditors could pursue the owners into bankruptcy, which could then lead to debtors' prison for the investor and the work-house for his family. Clearly this was a disincentive to invest, unless one had direct oversight of the business activities. But this was a period of great economic growth, generated by the industrial revolution, firms needed external capital to expand faster than ploughedback profits would allow.

The French were the first to create a form of corporate incorporation, which restricted shareholders' liability. From 1807, the Société en commandité par actions limited the liability of external investors, but maintained executive directors' personal exposure to corporate debt. These regulations were tightened in 1856. 
Meanwhile in Britain, the need for companies to access capital without exposing external investors to the threat of bankruptcy was debated in Parliament. Some Members of Parliament called for a form of incorporation that mirrored the French system. But in the event the British Companies Acts of 1855 and 1862 gave limited liability to all shareholders, whether they were involved in the management of the company or not.

It was a brilliant invention. The company was a legal entity with many of the attributes of a real person: it could contract, employ, own assets and incur liabilities, yet the shareholders were no longer responsible for the company's debts. Its existence was independent of the shareholders and its shares could be sold. Nevertheless, ownership remained the basis of power over the company. The shareholders appointed the directors, who reported to them. That underlying concept is still the underpinning of all modern companies, though the reality of power is now very different.

The opportunity to incorporate companies which limited shareholder liability proved very successful. The writers of the Savoy operas, Gilbert and Sullivan (1893) satirised the trend in their opera Utopia Ltd.

And soon or late I always call

for Stock Exchange quotation.

No scheme too great, and none too small

For companification!

All hail, astonishing fact!

All hail, invention new, The Joint Stock Company Act of Parliament Sixty-two. 
During the $19^{\text {th }}$ century many of the states within the United States passed legislation to allow the incorporation and control of companies. But the right of individual states was challenged at the federal level. In 1819, the United States Supreme Court over-ruled the lower court in the state of New Hampshire, which had revoked the royal charter given to Dartmouth College by the English King George the third. Many states saw this as a federal attack on state sovereignty and rewrote their laws to circumvent the Dartmouth ruling (Friedman, 1973). To this day, companies in the United States are incorporated at the state not the federal level.

The arrival of the industrial age in the United States brought great wealth to some companies and their owners. State constitutions were amended and laws re-written to be more amenable to companies. Shareholder limited liability arrived. Charter battles were fought to allow conglomerates. Eventually, corporate charters ceased to limited companies' activities and their life span.

The concept of the limited-liability company spread throughout British Empire of the late- $19^{\text {th }}$ century. The company law of Australia, Canada, some Caribbean islands which are now tax havens, India, Malaysia, New Zealand, Singapore, South Africa and other African countries still reflect those origins. Moreover, although countries' laws and regulations evolved to reflect their changing circumstances, Commonwealth case law can still be used as precedents. Hong Kong, now a special administrative region of China, still retains its British-orientated company law and legal system.

\section{The late 19th and early 20th centuries - corporate groups and private companies}

During the $19^{\text {th }}$ century companies in the UK were incorporated as public companies to raise capital. Each company was a stand-alone entity. There were mergers and amalgamations, but rather then form corporate groups, typically a new company was formed to take over the assets and liabilities of the merging companies, 
which were then wound up. But around the turn of the century, it was realised that in many jurisdictions, limited companies could own shares in other limited companies. The corporate group had arrived, with a holding company, and pyramids and chains of wholly or partly-owned subsidiaries.

Another development in the later years of the nineteenth and early twentieth centuries was the incorporation of companies, not to raise capital, but to provide the protection of limited liability to family firms and new entrepreneurial manufacturing businesses. This trend was recognized in Britain by the Companies Act 1907, which introduced the concept of the private company, with fewer restrictions on disclosure since it was restricted in size and not allowed to raise funds from the public. Today, of course, the number of private companies far exceeds those incorporated as public companies in all jurisdictions.

Now the original nineteenth century concept of the limited-liability public company, with ownership at the heart of power over the company had become diluted (Dunlavy, 1998). Around the world, the early years of the twentieth century saw significant economic problems. But the growing size of corporate enterprises and the increasing number, geographical spread, and diversity of their shareholders' led to a shift of power from shareholders towards boardrooms. In their seminal study, still one of the most cited works in the corporate governance lexicon, Berle and Means (1932, pages 44 and 82/83) demonstrated this shift of power in large United States corporations. They expressed concern about the growing power of large companies in society, observing that:

“...the huge corporation has come to dominate most major industries if not all industry in the United States.” 
“...management can become a self-perpetuating body even though its share in ownership is negligible...The usual stockholder has little power over the affairs of the enterprise and his vote is rarely capable of being used as an instrument of democratic control. The separation of ownership and control has become virtually compete." The updated 1968 edition (page preface $x x x$ and 82) concluded that: “...the ultimate ownership of the big (American) corporations has become ever more widely dispersed, and control has become increasingly separated from ownership."

Economic problems, the need to restore shareholder rights, and perhaps reign in overly-powerful corporations led to the creation of the US Securities and Exchange Commission (SEC) in 1934, providing some protection at the Federal level for investors even though US corporations could only be incorporated at the level of the state.

\section{The 1970s - audit committees, industrial democracy, and corporate accountability}

Interestingly, following the Berle and Means study, little interest was shown in the governance of companies for over forty years: in the $20^{\text {th }}$ century the focus swung towards management activities. But in 1972, the SEC required US listed companies to create a standing audit committee of the main board, composed of independent outside directors, to act as a bridge between the external auditor and the main board, ensuring that directors became aware of any issues that had arisen between the auditor and the company's finance department. A 1977 UK Parliamentary Bill, which would have also required audit committees, failed because although many listed companies had non-executive directors they tended to be in a minority, and the concept of independence in directors did not exist (Tricker, 1978). 
During the 1970s, the European Economic Commission (EEC) issued a series of draft directives seeking company law harmonisation throughout the member states. The draft fifth directive, in 1972, proposed that the unitary board system, in which the board of directors had both executive and outside members, be replaced by the twotier executive board and supervisory board governance system practised in Germany and Holland, in which a supervisory board monitors and oversees the work of an executive board, which runs the business. The German supervisory board also reflected the concept of co-determination, with equal numbers of employee and shareholder representative members. The British response was a report by Lord Bullock (1977), which suggested that the unitary board should continue, but include worker directors elected by the employees. Neither the EEC's directive nor the Bullock proposals were well received and neither was accepted. The 1970s also saw calls in both the United States and Britain for a rethink of the place of large corporations in society, a call which was to disappear during the free-market years of the 1980 's, only to reappear more recently as an interest in corporate social responsibility.

\section{The 1980's and 1990's - corporate abuse and corporate governance codes}

In the early ' 80 s, concerns about the way companies were controlled and held accountable were over-shadowed by their commercial success. But later in that decade the phrase 'corporate governance' appeared. Although, it has to be admitted, developments in the subject were responses to corporate collapses, board level excesses, and dominant chief executives and chairman, rather than the result of academic, research-based deliberations.

In the United States, the investment house Drexel, Burnham, Lambert was investigated by the SEC in 1986 and accused of insider trading, stock manipulation 
and failure to disclose ownership. According to the court papers, Michael Milken, head of its junk-bond department, had a secret agreement with Ivan Boesky, another name to go down in corporate governance history, to exchange insider information and hold stock for each other in violation of securities law.

In Australia, a 1989 report from the National Companies and Securities Commission, on the collapse of Rothwells Ltd. a listed financial institution, commented that "at no time did the board perform its duties satisfactorily." The stock market collapse in late 1987 provided the catalyst that finally brought the company down, though earlier the auditors had refused to sign the 1988 accounts, and the official report disclosed "massive private drawings and failure to disclosure loans to directors".

In Japan, Nomura Securities was accused of having too close links with their regulator, having offered well-paid sinecures to senior bureaucrats on retirement. Lavish payouts to major institutional clients to cover losses and links with a yakuza underworld syndicate were also alleged.

In the UK, Robert Maxwell built up a massive publishing empire during the ' 80 s despite an admonition that he had received in the 1970s from government inspectors never to run a public company again. The Robert Maxwell Group plc owned nearly half of two other listed companies - the Maxwell Communication Corporation plc and the Mirror Group Newspaper plc. Maxwell dominated both these companies and their directors, resenting any form of criticism. In 1991, he drowned in suspicious circumstances, leading the banks to call in the company's massive loans. The companies could not respond and an inquiry discovered that Maxwell had secretly withdrawn hundreds of millions of pounds from his companies' pension funds to save the companies from bankruptcy. 
Such scandals and the abuse of board-level power around the world led to calls for a rethink of the way companies were directed and held accountable at the top. In the United States, the Treadway Commission, formed in 1985, considered fraudulent corporate financial reporting. Their first report ${ }^{\mathrm{i}}(1987)$ led to the creation of the Committee of Sponsoring Organizations of the Treadway Commission ${ }^{\mathrm{ii}}$ (COSO), a private-sector initiative to encourage executive management and boards towards more effective business activities.

Other countries produced corporate governance codes. The UK's Cadbury Report (1992) on the financial aspects of corporate governance was the first. It called for the wider use of independent non-executive directors, the introduction of an audit committee of the board with independent members, the division of responsibilities between the chairman of the board and the chief executive, the use of a remuneration committee of the board to oversee executive rewards, the introduction of a nomination committee with independent directors to propose new board members, and reporting that the corporate governance code had been followed or, if not why not.

Following the Cadbury Report many other countries with financial markets published their own code - Australia, Canada, France, Hong Kong, Singapore, South Africa and many others ${ }^{\mathrm{iii}}$. International organizations including the OECD, the World Bank and the Commonwealth ${ }^{\text {iv }}$ produced corporate governance guidance, principles and codes of good practice. Some institutional investors and individual companies also produced corporate governance codes. As well as producing the first corporate governance report, Britain has subsequently produced 11 further corporate governance reports ${ }^{\mathrm{v}}$, more than any other country to date. The Australian Stock Exchange codes and the King reports from South Africa are noteworthy since they emphasise the need for companies to take an inclusive view of their relationships, not 
only with shareholders, but other groups in society affected by their activities, and introduced the ethical element in corporate governance activities.

The phrase 'corporate governance' also arrived in the 1980s and was quickly adopted world wide. Cochran and Wartick (1988) published an annotated bibliography of corporate governance publications: it had 74 pages. Today, Google accesses over 12 million references to corporate governance and Bing 23 million. Research into corporate governance also began to develop in the late 1980s. Corporate Governance - an International Review was founded in 1992.

\section{The late 20th century - complex corporate groups, complex ownership relations}

In the later part of the twentieth century, multi-national companies expanded dramatically, both through internal growth and external merger and acquisition. Many groups of companies now operated globally and had become complex from a governance perspective. Some had massive pyramids of wholly or partly-owned subsidiaries and associated companies held at many levels, but with each member company incorporated as a legal entity, with its board of directors, auditors, and governance and reporting requirements. Other groups were organized in networks of complex cross-holdings, sometimes as the result of joint ventures or mergers and acquisitions, sometimes for strategic reasons (as with the Japanese keiretsu), and some to obtain tax benefits or to take advantage of limited disclosure.

Another governance arrangement, found particularly in Italy, Hong Kong and some other jurisdictions, was the formation of chains of listed companies. Lead shareholders could then leverage financial control over the other companies in the chain and, consequently, exercise operational control over companies lower in the chain, whilst owning only a small fraction of their voting equity. Some companies were now also listed on exchanges around the world. Whilst in some countries, 
particularly China and Russia, this was the era of the privatization and partial listing of state enterprises.

During the 20th and early 21 st centuries, shareholders lost significant power over widely-held public, listed companies. No longer were they appointing directors. The nomination process in many countries had been usurped by incumbent directors, and the election process had become a façade with proxy votes. Institutional investors now held a significant proportion of the shares on many exchanges, but calls on them to exercise more governance power seldom carried real weight. Sovereign funds from export-benefitting and oil rich countries were also now investing in companies in other countries. Further diversity was added as some exchanges introduced secondary boards to invest in smaller, riskier ventures, typically with new and sometimes relaxed listing rules.

Moreover, strings of agents now frequently stood between the ultimate owner of a share and the company in which those funds were invested: brokers, agents, sponsors, share registrars, institutional investors, pension funds, and hedge funds, for example. All had the potential to filter relations between company and its ultimate owners, and distort voting rights. The original corporate concept of the limitedliability company had become debased, diluted, and distorted: although the essential idea remained that shareholders' liability for their companies' debts was limited.

\section{Contemporary frontiers of corporate governance}

The first generation of international corporate governance research typically examined governance mechanisms such as board composition and equity ownership in individual countries, mirroring the U.S. research that had preceded it. The second generation of international corporate governance research, however, recognized the 
impact of differing legal systems on the structure and effectiveness of corporate governance and compared systems across countries (Denis and McConnell, 2003).

It is now widely recognized that context and culture ${ }^{\mathrm{vi}}$ play a significant role in determining corporate governance practices around the world. Defining corporate governance as the way power is exercised over companies, three broad categories can be identified:

The dispersed ownership model is prevalent in the US, the UK, and some

Commonwealth countries, whose legal systems are based on common law building on legal case precedents. In this model equity ownership is spread among institutional investors and individuals with none dominating, stock markets are liquid, with a strong market for control of the corporation. The corporate governance structure employs unitary boards with independent outside directors.

The concentrated ownership model is found in some Continental European countries and countries previously influenced by them, whose legal systems are based on civil law relying on the legislature's enactments. Stock markets tend to lack liquidity and there is a poor or no market for corporate control. Companies are financed by nonequity interests as well as equity ownership. The corporate governance structure uses two-tier boards with separate supervisory and executive boards.

The dominated ownership model includes Asian networked groups ${ }^{\mathrm{vii}}$ such as the Japanese keiretsu and the chaebol of South Korea, listed companies with majority family ownership as found, for example, in some Continental European countries and Hong Kong, and privatized, listed but state-dominated companies in, for example, Singapore and China. The legal system reflects the local context, culture and, sometimes, political situation. Stakeholder interests can be as important as equity 
ownership. Diverse corporate governance structures reserve significant power to the dominating interest.

Figure 1 about here

The three basic models emphasise the significance of context and culture in understanding corporate governance around the world. Clearly, this paper cannot explore these different governance practices in detail, but a brief survey may help to emphasise the cultural significance of the three models distinguished above.

\section{Contemporary corporate governance in Japan}

Keiretsu are networks of Japanese companies connected through cross-holdings, frequently including a financial institution, which tend to inter-trade extensively. The classical model of the keiretsu reflects the social cohesion within Japanese society, emphasising unity throughout the organisation, non-adversarial relationships, lifetime employment, enterprise unions, personnel policies encouraging commitment, initiation into the corporate family, decision-making by consensus, and with promotion based on loyalty and social compatibility as well as performance.

Traditionally, investors have played a relatively small part in corporate affairs. The classical model of Japanese corporate governance has a stakeholder rather than a shareholder orientation. Power lies within the keiretsu network. In the classical keiretsu model, boards of directors tend to be large and are, in effect, the top layers of the management pyramid. Independent outside directors have no place in the classical model. Some directors may have served with other companies in the keiretsu network, others might have been appointed from amongst the industry's government regulators (known as amakaduri or "those descended from heaven"). However, the classical 
model has recently come under pressure with challenges from overseas institutional investors and reflecting the country's continuing economic weakness. In 2008, eight international investment funds called for greater shareholder democracy and a report from the Japanese Council for Economic and Fiscal Policy suggested that anti-take over defences should be discouraged. New company law was introduced which permitted an alternative, more Anglo-American form of corporate governance with independent outside directors. But few companies have yet embraced this approach.

\section{Contemporary corporate governance in South Korea}

Chaebol groups ${ }^{\text {viii }}$ in South Korea developed after the Second World War when the government advanced loans on attractive terms to existing family-based firms to stimulate economic revival. Over time some of these firms prospered and became large groupings of associated companies. Despite public listing, many chaebol groups are still controlled by dominant family interests. Attempts to introduce independent outside directors into South Korean boards have had only limited effect against the entrenched power of the existing block owners. At times this has led to protests from employees. The South Korean Government has endeavoured to reduce the power of the chaebol, through enforced sales of companies in the groups, with limited results.

\section{Contemporary corporate governance in Overseas Chinese family companies}

Research into the management of overseas Chinese ${ }^{\mathrm{ix}}$ companies has suggested some distinguishing characteristics, which highlight governance practices (Redding and Wong, 1986, Redding 1993). Studies suggest that overseas Chinese companies, even though listed, are typically family centric with close family control, through a majority equity stake kept within the family. The companies tend to be entrepreneurial, often with a dominant entrepreneur so that decision making is centralised, with close personal links emphasizing trust and control, paternalistic in 
management style, in a social fabric dependent on relationships and social harmony, avoiding confrontation and the risk of the loss of "face", and strategically intuitive with the business seen as more of a succession of contracts or ventures, relying on intuition, sometimes superstition and tough-minded bargaining rather than strategic planning, brand-creation and quantitative analysis.

Many Hong Kong family-dominated, listed companies, though having to follow the stock exchange listing rules and conform to the regulation of the Hong Kong Securities and Futures Commission, are incorporated in overseas tax havens. Typically outside shareholders are in a minority, and the regulatory authorities emphasise the importance of disclosing and controlling related party transactions.

\section{Contemporary corporate governance in China}

Business enterprises in China can be classified into three types. State-owned enterprises (SOEs), which vary in size, can be owned at the national, provincial or local level. Many have been corporatized, and partly privatized through listings in Shanghai, Shenzen, Hong Kong or overseas stock exchanges. Collectively-owned enterprises, including rural township and village entities (TVEs), and privately-owned organizations, which are defined as firms with more than seven employees, created from the privatization of state SMEs, or through the 'dual-track' provisions which allowed new enterprises to run alongside state enterprises, and small individuallyowned enterprises with less than eight employees (Leng Jing, 2009).

For the SOEs, China has created a unique form of corporate governance structure building on the practices of other countries around the world. This comprises a management board of directors, with at least a third independent outside directors, and a board of supervisors, with both worker representatives and other members - thus combining elements of both the German-style two-tier board model and the 
independent, outside directors of the unitary board, as well as recognizing China's traditional concept of employees being masters of enterprises (see figure 1).

However, unlike the German model, which calls for an equal number of shareholder and employee representatives, reflecting German co-determination law, Chinese company law does not specify the proportion of shareholders' representatives and employees' representatives on boards of supervisors, other than requiring at least a third to be worker representatives. Moreover, the supervisory board in China lacks the power to hire and fire directors and has no direct responsibility to the shareholders as in the Germany model. Consequently the formal power of the Chinese supervisory board is relatively weak and it has to act through influence, such as the chairman being the local Communist party representative.

A unique aspect of the governance of China's listed SOEs is the role played by the state. The China Securities Regulatory Commission (CSRC) is the formal regulator, liaising with the SOEs and stock exchanges, developing corporate law and governance codes, and ensuring reporting and compliance. The State-owned Assets Supervision and Administration Commission (SASAC), on the other hand, holds the state's shares, effectively being institutional investor on the state's behalf. As such it is the largest institutional investor in the world. SASAC can play a significant role in the governance of companies, including the appointment and removal of CEOs, the approval of major investments and funding, and overseeing any strategic developments that might affect the interests of the people, represented by the Communist Party and, effectively, the State. As shown in figure 2, both SASAC and CSRC are tied to the State Council and ultimately the National People's Congress through links with government bodies. 
Figure 2 about here

\section{Contemporary corporate governance in the other BRIC countries}

The significance of China and the other BRIC countries - Brazil, Russia and India - to the world economy after the global financial crisis has become apparent. Consequently, the corporate governance in those countries has acquired a new significance.

Russia

Like China, Russia is a transitional economy which faced the need to privatize its state enterprises. But many Russian citizens were dubious about privatisation, believing that industry should be run by the state, that everyone should be guaranteed a job, and that incomes should be controlled. To overcome resistance and make changes irreversible, the state transferred ownership in three ways: directly to all Russian citizens through the free distribution of vouchers, by investment tenders in which investors had to make substantial investments, and by loan-for-shares auctions of large enterprises. Fraudulent practices, violence and social injustice occured and many of the major businesses that emerged were dominated by relatively few people, many of them now very rich.

Initially the privatized companies adopted the unitary board structure, with some independent outside directors, reflecting the US and UK/Commonwealth models. But ownership concentration was high, and companies were dominated by controlling shareholders, often the previous managers. Minority shareholders saw their rights violated. Moreover, state interests sometimes took precedence. Faced with the domination of many boards and widespread corruption, there was a call for a better understanding of corporate governance. 
A Russian corporate governance manual was produced with advice from the OECD and the International Finance Corporation. Under the corporate governance code and company law, companies are governed by a board of directors (sometimes confusingly called the supervisory board) with both independent directors and management directors, elected by the shareholders, and an executive (or management) committee of the board.

Today there is more transparency, standards for corporate governance are more widely understood, many of original managers have been changed, and losses through unfair practices has been reduced. But since the presidency of Vladimir Putin, the role of the state has expanded and government influence over some companies has increased. Some ownership has been transferred back to the state by acquisition or expropriation.

India

As with China and Russia, history played a part in the development of Indian corporate governance. India was part of the British Empire ('the jewel in the crown' of Queen Victoria) and like Hong Kong and Singapore benefited from the early creation of government administrative processes, with a reliable rule of law including company law backed by a reliable judiciary.

Following independence, India took a socialist road with large state-owned enterprises and the public sector dominating the economy. Bureaucracy grew and inefficiency, corruption and nepotism flourished. By the 1990s the need for India to develop its business infrastructure and attract capital was recognised. The first corporate governance code was published in 1998 by the Confederation of Indian Industry (CII). A year later a government committee released India's National Code on Corporate Governance. Reflecting international standards, the code was approved 
by the Securities and Exchange Board of India (SEBI) and incorporated into stock exchange listing rules.

Corporate governance standards in India's top-tier listed companies are high. But this commitment is not yet general. Small and medium capital companies often seem unconvinced of the value of corporate governance activities and expenditures. As in other parts of the world, interest in corporate governance in India was a reaction to corporate scandals, including stock price manipulation. In 2002, reflecting international concern following the USA Enron debacle, the Indian government set up a high-level committee to examine corporate auditing and independent directors. The report called for independent directors to represent at least $50 \%$ of the board of listed companies, strengthened the definition of independence and called for the rotation of audit partners (but not audit firms).

In many companies in India, boards are dominated by majority shareholders. Pre-emption rights for minority shareholders are frequently ignored. Competent regulators and capital market action are needed to protect minority investors. A corporate governance rating by the Asian Corporate Governance Association assessed India's corporate governance as 'fair to poor'.

Brazil

In Brazil, many companies are either state-owned or family-dominated. The Brazilian Institute of Corporate Governance was founded in 1995 and in 1999 produced the Brazilian Code of Best Practice of Corporate Governance ${ }^{\mathrm{x}}$, which is now in its fourth edition (2009). Brazil's economy is booming, despite a Byzantine tax system and endemic poverty and corruption (Shachar, 2010). But Brazilian company law and the code have three unusual corporate governance features - the fiscal council, the family council, and the advisory board. 
A fiscal council can be established under a company's Articles of Incorporation, or at the request of shareholders. The role of the council is to inspect the work of the board and the activities of the company, to ensure compliance with legal and statutory duties, to provide an opinion on the annual management report and on significant board proposals for investment plans, changes to capital, and dividend payouts. The fiscal council is required, at least quarterly, to analyze and comment on the financial statements and provide an opinion to the shareholders general meeting on board proposals. Fiscal councils have the right to consult with outside professionals, and are typically recognized as adding value to the company's owners by providing independent control.

In family-dominated companies in Brazil, the code encourages the creation of a family council, whose role is to discuss family issues and the alignment of its members' expectations with those of the other shareholders. Family councils enable boundaries to be set between family and company interests, the preservation of longer-term family values, and the formalization of succession planning for family members in both management and on the board. Family councils can also consider issues of inheritance and the transfer of property, which cannot properly be considered by the shareholders' meeting.

The articles of association of some Brazilian companies also provide for an advisory board. The code suggests that "the existence of an advisory board, preferably made up of independent members, is good practice, particularly for organizations taking the first steps in the adoption of good practices of corporate governance. It allows independent members to contribute to the organization and gradually improve its corporate governance." The code calls for the advisory board's performance to be guided by the same principles that govern the Board of Directors. 


\section{The central thesis and argument of this paper}

The evolution of the limited-liability company has now been traced from the elegantly simple and superbly successful concept of the $19^{\text {th }}$ century to the complex, diverse and massive operations that typify listed companies today. The original basis for power ${ }^{\mathrm{xi}}$ over companies was ownership. But over the years that power has swung from owners to directors, to the extent that today shareholders, even institutional shareholders, have relatively little power over the companies they own. This supports the central thesis of this paper: that the original concept of the limited-liability company no longer reflects reality, the essential model has been corrupted. Yet this concept is still the basis for company law and corporate regulation around the world. The relevance of the context and culture of company law jurisdictions and financial market regulation has also been shown.

Society today is no longer satisfied with corporate behaviour. Evidence is widespread. Questions are asked about tax-payer support for failing financial and manufacturing companies. Many people see no reason for tax-payers to be liable for corporate debt, just because theses companies are 'too big to fail'. Perceptions of top management greed, remuneration excesses, and the dilution of shareholder value through large top management rewards are widespread. Calls are heard for controls on allegedly excessive top management remuneration, including golden handshakes, golden parachutes and equity-linked performance bonuses, particularly where they seem to be rewards for failure. Many cases have been reported of top management domination and abuses of power. Calls for stakeholder involvement are heard, and corporate governance reports increasingly emphasise CSR, sustainability, ethics, and enterprise risk management. 
The originators of the limited-liability company in the 19th century created a corporate governance system in which society required them to meet specific roles and responsibilities, and bounded their activities. This highlights the central argument of this paper: companies again need to be held responsible for meeting societies' expectations. Incorporating a company, in which shareholders are not responsible for their company's debts, should require them to meet societies' expectations.

Otherwise shareholders should accept responsibility for those debts.

Limited liability is a privilege not a right. What society grants, it can take away. Power in society should be exercised through its legislators, not by companies through their directors. In other words, if a company wants limited liability it needs to meet societies' expectations. The concept of the corporation needs to be re-invented to reflect present circumstances and meet society's expectations.

\section{Re-inventing the limited liability company - the need for a taxonomy}

However, before such thinking can be developed, a dilemma has to be resolved. The classification of corporate entities has not changed for over 100 years. Around the world, limited companies are still divided into just two categories: public and private (those that can invite the public to subscribe for their shares and those that cannot).

Today that is a totally inadequate categorization of corporate entities. Before we can pursue the radical suggestions in this paper a classification scheme or taxonomy is needed that distinguishes different species and sub-species of corporate entity. Too many different types of corporate entity are currently treated as though they were homogeneous. One approach might be to differentiate ownership and governance structures. In other words, the way that power is, or could be, exercised over companies might provide a basis for distinguishing corporate types. 
What different types of company might be recognized if the limited company was to be re-invented today? Further research will be needed to develop a tenable taxonomy of corporate entities, but the following may trigger some thoughts. The first major category could be public companies that is those with external investors. Subcategories might differentiate widely-held listed companies, listed companies dominated by a single or a group of shareholders, and listed companies dominated by another listed company. The public companies category could also embrace, state chartered companies with a minority of their shares listed, and public companies not listed on a stock exchange. The second major category could be private companies, sub-divided into group holding (parent) companies, wholly owned subsidiaries of a group holding company, subsidiaries of another company not a holding company, partly owned subsidiaries, associated companies dominated by another company, private equity firms incorporated as companies, private companies held by family interests, and joint venture companies. A third major category could embrace partnerships, trusts and co-operatives, sub-divided into partnerships without limited liability, partnerships with limited liability, private equity firms, hedge funds, sovereign funds, and co-operatives.

Such a categorization would need to cover all types of corporate entity in every jurisdiction, including, for example, South Korean chaebols, Japanese keiretsu and Italian chained companies. It would need to include entities in different cultures, with different legal systems, institutions, and regulatory bodies. There also seems little justification for excluding other corporate types such as NGOs, charities, professional bodies and not-for-profit organizations.

As with all eco-systems, diversity tends to be useful. The rich variety of governance and organizational forms shown above suggests that the frontiers of 
corporate diversity, far from converging, are evolving and multiplying fast. Indeed, it can be argues that the era of the listed, public company has reached its zenith.

Nevertheless, such companies still form the backbone of investment around the world, and are the corporate governance form considered further in this paper. Other researchers need to pursue the governance of alternative business forms.

\section{Re-inventing the limited liability company - unresolved issues}

Before the company can be re-invented for the 21 st century a fundamental philosophical issue will have to be resolved: how do societies believe power should be exercised over companies in their midst? The economic, social and political context today is vastly different from that of the nineteenth century when the limited company was first invented. The scale, diversity and significance of companies are of a different order. A discussion is needed on the rightful place of companies in society (Friedman, 2002, 2008). Such a discussion has already begun as can be seen in the widespread interest in corporate social responsibility and sustainability. The work of the Tomorrow's Company organization has been pursuing related issues for some years ${ }^{\mathrm{xii}}$. Obviously, the dimensions of such research and the ensuing debate are immense and, hopefully, this journal and its readers will make an important contribution.

Before a satisfactory corporate governance model can be developed three corporate governance paradoxes also need to be resolved. These might be called the principle or rule paradox, the ignorance of independence paradox, and the conformance/performance paradox.

\section{The principle or rule paradox}

Many commentators refer to the 'Anglo-American' approach to corporate governance. They contrast the unitary board, which has both executive and non- 
executive directors in the Anglo-American common law jurisdictions, with the two tier, supervisory and executive boards of the Continental European and other civil law countries.

But in reality there are fundamental differences between American and British concepts of corporate governance. The under-pinning of American corporate governance is mandatory governance determined by law: follow the legal requirements or risk the penalties. By contrast the basis of corporate governance in Britain and other Commonwealth countries, whose company laws reflect earlier British influence, rely on a discretionary approach of governance by principle: comply with the code or explain why the company has not.

Some years ago there was a widespread belief that corporate governance around the world would gradually converge on the American model, not least because the world needed access to American capital. That is no longer the case. So this paradox remains unresolved.

\section{The performance/conformance paradox}

The second paradox relates specifically to unitary boards, which are responsible for ensuring both the performance of the enterprise and its conformance. In other words, the board is expected to be involved in strategy formulation and policy making, whilst also supervising management performance and ensuring accountability. It has been suggested that this means the unitary board is effectively marking its own examination papers. Of course, the two-tier board structure avoids this problem by having the executive board responsible for performance and the supervisory board for conformance, with no common membership allowed.

To overcome the apparent dilemma of the unitary board, corporate governance codes call for independent outside (non-executive) directors to play a vital role. 
Independence is precisely defined to ensure that these directors have no interest in the company that might, or might be seen, to adversely affect genuine independent objective judgement. The number or percentage of independent board members on the board is often specified. Audit, remuneration and nomination committees of the board must be mainly or wholly comprised of independent, outside directors. But that leads to the third paradox.

\section{The independence paradox.}

The definition of independence in most corporate governance codes is exhaustive. To be considered independent a director must have no relationship with any firm in the up-stream or down-stream added-value chain, must not have previously been an employee of the company, nor be a nominee for a shareholder or supplier of finance to the company. Indeed, the definition of independence is so strict that an independent director who has served on the board for a long period is often assumed to have become close to the company and is no longer independent.

Herein lays the independence paradox. The more independent a director is, the less he or she probably knows about the company or its industry. The more nonexecutive, outside directors know about a company's business, organization, strategies, markets, competitors, and technologies, the less independent they become. Yet such people are exactly what top management needs to contribute to its strategy, policy making and enterprise risk assessment.

A commission appointed by the New York Stock Exchange (NYSE) recently reflected this concern in ten core principles of corporate governance ${ }^{\text {xiii }}$. Whilst the Commission supported the NYSE's listing requirements, which call for a majority of independent directors, it also pointed out that companies can have additional nonindependent directors so that there is an appropriate range and mix of expertise, 
diversity and knowledge. The Commission argued that while independence is an important attribute for board members, the NYSE's Listing Standards do not limit a board to just one non-independent director and boards should seek an appropriate balance between independent and non-independent directors.

Similar questions can be raised about an independent chairman of the board. Most corporate governance codes call for a separation between chairman and chief executive. Even in the United States, where the roles have traditionally been combined in a single powerful figure, there have been calls for them to be separated.

\section{Re-inventing the limited liability company - changing the balance of power}

Previous suggestions for changing the balance of power over companies include Dallas (1997) who proposed dual boards and a board ombudsperson, Turnbull (2000) who made a case for compound boards, and Hatherly (1995) who called for shareholder panels. Other proposals to legitimize shareholder control include Guthrie and Turnbull (1995) and Turnbull (2002) who proposed corporate senates and stakeholders councils. The Australian Parliament considered similar proposals for corporate governance boards for IPOs (Murray, 1998). Brazilian fiscal councils, mentioned earlier, can also give shareholders more power over their company.

This paper focuses on the governance of listed limited-liability companies. The taxonomy, proposed above, would differentiate between ownership types and thus identify the ability to exercise power; for example distinguishing between widely-held companies with no dominant holders, listed companies in a chain dominated by other owners, and state chartered companies with a minority of voting shares listed. An alternative governance model would also need to satisfy both legal requirements and cultural expectations of the states in which it operates. 
What might the listed limited-liability company look like if it was re-invented to reflect contemporary reality? In formulating an alternative, three parties need to be recognized: investors in the entity, executive management of the enterprise, and all added-value stakeholders, including employees, those in the up and downstream added-value chains, and the suppliers of debt finance.

The following framework (figure 3) has been designed to reflect the legitimate interests of these three groups. The interests of the wider publics who might be affected by corporate activities, such as local communities, provincial interests or federal state concerns have been excluded from the re-invented governance model, on the grounds that their interests might more properly be reflected in other legislation.

\section{Figure 3 about here}

In describing the new framework, labels such as 'board of directors', 'supervisory board', or 'committee' have been avoided because they come heavily laden with pre-conceptions and prejudices. Instead, the proposed framework adopts alternative names - Governing Body, Executive Management, and Stakeholder Liaison Groups - for the governance structures designed to meet the interests of the three legitimate interest groups.

The role of the Governing Body is to ensure that shareholder interests are represented and met. This is an investor board with its members nominated and elected by the shareholders. It would provide a forum for all classes of voting member in the company. In a widely-held listed company the institutional investors would probably play a significant role. In a dominated listed company the dominant interests would take the lead but ensure that minority interests were protected. In a family company 
the family shareholders, probably advised by a family council, would take the lead but again protecting minorities. Members of Governing Bodies would probably include those with previous experience as independent outside, non-executive directors, and a new professional cadre of professional Governing Body members could evolve.

Investors in listed companies can be categorized between long-term owners and those interested mainly in short-term profits, whom some would call speculators. If long-term investors behave like owners, they would look to the company's longterm success, not short-term share price movements. It seems reasonable for different rules to apply to each type, with the right to elect to the governing body being restricted to long-term investors. Institutional investors, including insurance companies, pension funds, hedge funds, and in some cases sovereign funds, can adopt either investment strategy.

The Governing Body would have the power to appoint and approve the rewards of the chief executive, approve top management remuneration, receive reports from the auditors, approve strategies and policies, and ensure subsequent conformance, confirm that risk management and other control systems function, approve financial policies, fund raising, and dividend policy, and seek independent advice.

In fulfilling this role, the Governing Body would take on the roles of the present audit, nomination, and remuneration committees of the unitary board. Separating the responsibilities of the Executive Management from those of the Governing Body overcomes the independence and performance/conformance paradoxes discussed above.

Critics of this structure might argue that these proposals introduce the Continental European two-tier board. Not so. There are no employee members, no 
German codetermination, and no Dutch socially responsible members. Shareholder power would be restored to the owners.

The Executive Management is the top management group of the organization, the executives in the top management team. The chief executive and other senior officers would be appointed much as they are now, with the Governing Body acting as a nominating committee, possibly with ratification by the shareholders' meeting. The Executive Management would have no independent outside members and could be supplemented by external, non-executive members to provide additional experience, relevant knowledge and business support. They would not need to be independent in the conventional sense.

The role of the Executive Management would be to run the enterprise, developing its strategies, creating its policies, and achieving the aims and performance goals agreed by the Governing Body. Non-executive members of the Executive Management would provide the deliberations and decisions of the Executive Management with valuable information and insights, based on their relevant knowledge of the business, the industry, and its markets. These non-executive members would bring an independence of mind, but not the independence of ignorance, thus overcoming the independence paradox discussed above.

In essence, the Executive Management would consist of the chief executive and the top executives plus informed non-executive members to supplement their work. Many boards of directors today are, in effect, self-appointed, self-rewarding and self-perpetuating elites. Separating the roles of the Executive Management from those of the Governing Body would avoid such situations.

Stakeholder Liaison Groups are the third element in the proposed new corporate governance framework. Increasingly, corporate stakeholders, including 
employees, customers, corporate entities in the up and down-stream added-value chains, and suppliers of debt finance, are seen as inherently part of corporate governance responsibility. Sound corporate governance recognizes their legitimate, long-term interests in their relations with the company. Stakeholder Liaison Groups would work with both the Executive Management and the Governing Body providing three-way communication on matters of mutual interest. These groups would have advisory responsibilities with no executive powers to determine company affairs beyond those provided by law.

Stakeholder Liaison Groups would be formed to represent the interests of appropriate stakeholder groups. The liaison group to represent employee interests would assume the role of the works council in some companies. Clearly, the principle of Stakeholder Liaison Groups, as with the other proposals, would need to be reflected in legislation, created by companies' charters or articles of association, and initially formed by the company promoters.

\section{Re-inventing the role of auditors}

As we have seen, in the original 19 th century model of the limited-liability company the state permitted incorporation of limited-liability entities provided safeguards were met to protect society. Auditors, appointed from amongst the shareholders, reported to them that the directors of their company had faithfully recorded the company's financial situation and demonstrated their stewardship over its assets.

Then the accounting profession emerged. Small audit firms at first but, as companies grew in scale and complexity, they grew larger. Changes to partnership law and mergers enabled them to grow further. By the end of the twentieth century the world's major listed companies were audited by just five vast, international accounting 
firms, which became four on the collapse of Arthur Andersen, following their involvement in the Enron debacle.

These accounting firms are major businesses, offering products and solutions, with partners judged by fee generation, growth and profit performance. Serious questions have to be asked about the auditors' position. Who are their real clients: the directors or the shareholders? The de jure response that the client is the company and that somehow this means the body of shareholders will no longer wash. The de facto reality is that the client is the board, backed up by the board's audit sub-committee. Is this satisfactory? What are the alternatives?

Some have suggested splitting the big firms, or opening the market for audit, with second tier firms playing an increasing role in the audit of major listed companies. But financial markets like the assurance they believe they get from an audit opinion signed by one of the big four firms. Others have proposed further rules to regulate auditors' activities, like the US Sarbanes Oxley Act (SOX), for example. But SOX has proved more expensive and less effective than expected, as seen in the subsequent collapse and bail-out of financial institutions and some other companies.

The proposal in this paper is that auditors are appointed by and report to the regulators as well as the Governing Body. It is the state that permits companies to incorporate, and the state that is responsible for protecting the interests of investors, creditors and other stakeholders. The regulatory organizational structures already exist to manage such a relationship. The regulators, liaising with the Governing Body and shareholders in general meeting, would appoint, re-appoint or if necessary replace the auditors, agree their fees and receive their reports. The company would, as now, bear the costs. 
In this way close relationships between directors and auditors would be avoided. If auditors reported to the regulator rather than the directors, a new mind set would be needed. Moreover, shareholders would have a direct line to their auditors.

\section{Conclusions}

The $19^{\text {th }}$ century concept of the limited-liability company was simple and successful. But the growing diversity of corporate objectives, confused ownership structures, and complex corporate groups led to abuses. Society originally demanded strict controls and bounded objectives for the right to incorporate companies in which shareholder liability was limited. Faced with growing societal dissatisfaction with corporate behaviour, this paper calls for a re-invention of the rationale, purpose and governance of the listed limited-liability company.

Methodologically, this paper looks at corporate governance from an unconventional perspective, taking an evolutionary view and tracing the development of corporate governance thinking and practice over time and around the world. The key theoretical stance is that culturally-determined ideas are transmitted from person to person, society to society, and that theory can be developed from an understanding of how situations come to be constituted, reproduced and adapted.

A call was made for a taxonomy of corporate types to differentiate the many different corporate governance power structures that now exist. An embryonic list was suggested, but scholars from a variety of disciplines, including law, financial economics, and management need to contribute to the identification of the characteristics that distinguish corporate types by ownership category and to the development of a relevant scheme of classification that can be reflected in corporate governance law, regulation and practice. 
The paper also highlighted three unresolved dilemmas in corporate governance orthodoxy: whether governance should be by principles or rules, the potential ignorance of the business if outside directors are independent of the company, and the inherent conflict in a unitary board's dual responsibility for both performance and conformance.

The paper proposed an alternative governance paradigm for corporate entities, with a tri-partite balance of authority, power and responsibility between the Governing Body, the Executive Management, and Stakeholder Liaison Groups. It was further suggested that external auditors should report to the regulators as well as to the Governing Body. The roles and responsibilities of directors, executives, stakeholders and external auditors would be more clearly articulated, transparent and accountable. Such a re-invention of the limited-liability company would shift power over companies back towards their owners.

Further research, review and discussion are obviously essential, which would undoubtedly generate further ideas. A few avant-garde companies might develop and experiment with these ideas. But resistance to such changes would almost certainly be widespread, because the existing power-base would be changed. Moreover, unilateral action by any one jurisdiction could drive business (and the associated employment, economic contribution and tax base) to other less well-regulated jurisdictions. Ultimately international agreement and legislation would be needed.

These are radical proposals, too radical some will argue. The corporate world would never accept them. However, the debates in the British Parliament in the midnineteenth century show that not everyone was happy then with the original idea of limiting shareholders' liability for the debts of their companies. In fact, that is a lever that society still holds. Limited liability is a privilege granted by society, not an 
automatic legal right. Limiting companies' liability for the debts they incur involves a contract with society. If companies breach that contract they could lose the protection of that contract. What society grants through its legislators, society can take away if it is not satisfied with the way companies are managed or governed. Unless companies meet societies' expectations, investors should become liable for their companies' debts. The essential argument is that if society is not satisfied with the way companies are run, society has the solution in its own hands - agreeing or refusing to limit the liability of shareholders for their companies' debts.

\footnotetext{
${ }^{\mathrm{i}}$ Report of the National Commission on Fraudulent Financial Reporting (1987).

ii The Committee of Sponsoring Organizations of the Treadway Commission (COSO), is supported by:
}

American Accounting Association

Institute of Management Accountants

American Institute of Certified Public Accountants

The Institute of Internal Auditors

Financial Executives International

See www.coso.org

${ }^{\text {iii }}$ For access to international codes and corporate governance institutions see: 
http://www.ecgi.org/codes/all_codes.php

http://www.oecd.org/linklist/0,3435,en_2649_34813_2585769_1_1_1_1,00\&\&enUSS_01DBC.html

iv For complete list of Commonwealth members see http://www.thecommonwealth.org/Internal/191086/142227/members/

$\checkmark$ The 11 reports following the Cadbury Report were:

Greenbury Report (July 1995)

Hampel Report (January 1998)

UK Combined Code (1998)

Turnbull Report (1999 revised October 2005)

Higgs Report (January 2003)

Smith Report (July 2003)

Tyson Report (June 2003)

Revised UK Combined Code (July 2003)

Myners Report (December 2004)

Revised UK Combined Code (June 2006)

The UK Corporate Governance Code (June 2010)

vi 'Culture' is a word that has many dimensions, but here it is used to mean historical precedents, traditions, experiences, and expectations. 'Context' refers to the legal system and its reliability, the social, political, and (possibly) religious situation, and the state of economic development.

${ }^{\text {vii }}$ Machold. S \& Vasudevan. A.K, (2004) Corporate Governance Models in Emerging Markets: The Case of India, International Business and Ethics, pages 56 - 64

${ }^{\text {viii }}$ For more information see www.oecd.org/dataoecd/48/55/25778905.pdf

Also Kar .P, (2001) Corporate Governance in India, in Corporate Governance in Asia: Comparative Perspective 249, 251, 272-73, OECD

ix Diaspora from mainland China over the years has produced businesses around the Asia Pacific region run by Chinese entrepreneurs. Hong Kong, Singapore, Malaysia, Thailand and other countries all have many companies run by these Overseas Chinese 
${ }^{x}$ For a copy of the Brazilian Code of Best Practice of Corporate Governance go to http://www.ecgi.org/codes/all_codes.php

${ }^{x i}$ Using Mary Parker Follet's definition of 'power' as the ability to make things happen

xii http://www.tomorrowscompany.com/aboutus.aspx

xiii The New York Stock Exchange, 2010 - sponsored Commission on corporate governance, 10 Core Principles of Corporate Governance, October. The commission represented investors, issuers, broker-dealers, and governance experts 


\section{REFERENCES}

Jay B. Barney and William S. Hesterly, 2008, Strategic Management and Competitive Advantages. Pearson, Prentice Hall

Berle, Adolph A and Gardiner C. Means, 1932, The Modern Corporation and Private Property, London, Macmillan, pages 44 and 82/83. Revised edition Adolf Berle, 1967, New York, Harcourt, Brace and World, preface page preface $x x x$ and 82 Bullock, Committee, 1977, The Report of the Committee of Inquiry on Industrial Democracy, London, Her Majesty's Stationery Office

Carver, John, 1981, Is America Ready for Self-Governance: The Third Sector, In D.

Nachmias and A. Greer (eds.), The Crisis of Authority: Citizen Boards and the

Governance of Public and Private Agencies, University of Wisconsin-Milwaukee

Carver, John, 1984, Redesigning Governance in the Cities. Florida Municipal Record, 58, 2-4.

Carver, John, 1984, Professional Challenges for an Emerging Community: The

Challenge to Non-profit Governance. Proceedings of the 1984 Conference of the Nonprofit Management Association, San Francisco, June 6-10, 19

Carver, John, 2010, A Case for Global Governance Theory: Practitioners Avoid It, Academics Narrow It, the World Needs It, Corporate Governance: an International Review 18(2), 149-157

Cochran, Philip L and Steven L. Wartick, 1988, Corporate Governance - a review of the literature, Morristown, Financial Executives Research Foundation 
Coffee, John C, The Future as History - the prospects for global convergence in corporate governance and its implications, Columbia Law School Center for Law and Economic Studies, Working Paper No. 144

Dallas, l.l, 1997, Proposals for reform of corporate boards of directors - the dual board and the board ombudsperson, Washington and Lee Law Review, Winter, Volume 54.1 pages $92-146$

Dawkins, Richard, 1998 (2 edn,) The Selfish Gene, Oxford, The Oxford University Press, 192

Denis, Diane K. and John J. McConnell, International Corporate Governance, Journal of Financial and Quantitative Analysis (2003), 38: 1-36

Dunlavy, C.A, 1998, Corporate Governance in late $19^{\text {th }}$-Century Europe and the USthe case of shareholder voting rights, in Comparative Corporate Governance - the state of the art and emerging research, Klaus J, Hopt et al (eds), Clarendon Press, Oxford, pages 5-39

Friedman, L. M, 1973, A History of American Law, Simon and Schuster, New York Friedman, Milton, 2002, Capitalism and Freedom, University of Chicago Press Friedman, Milton, 2008, Milton Friedman on Economics - selected papers, University of Chicago Press Journals

Gilbert, Arthur and W.S. Sullivan, Utopia Limited or The Flowers of Progress, opened October 7, 1893 at the Savoy Theatre D'Oyle Carte Opera Company, Act 1, Finale

Guthrie, James and Shann Turnbull, 1995, Audit Committees - is there a role for corporate senates and/or stakeholders councils? Corporate Governance - an International Review, Volume 3, Number 2, April, pages 78-89 
Hatherly, D, J, 1995, The case for shareholder panel in the UK, The European Accounting Review, Volume 4-3 pages 535-553

Jensen, Michael A, 2000, A Theory of the Firm: Governance, Residual Claims and

Organizational Forms, Cambridge MA, Harvard University Press

Jensen, Michael A and William Meckling, 1976, A Theory of the Firm: Managerial

Behaviour, Agency Costs and Ownership Structure, Journal of Financial Economics

October 3(4)

Judge, William Q, Thomas Kuhn and Corporate Governance Research, Corporate

Governance -an International Review, Vol. 18, No. 2, 85-86

Langley, A, 1999, Strategies for Theorizing from process data, Academy of

Management Review, Vol. 24, No 4, 691-710

Langley A, 2007, Process Thinking in Strategic Organizations, Strategic

Organization, Vol. 5, No. 3, 271-282

Leng Jing, 2009, Corporate Governance and Financial Reform in China's Transition Economy, Hong Kong University Press, Hong Kong

McWilliams, Abagail and Donald Siegal, 2001, Corporate Social Responsibility: a

Theory of the Firm Perspective, The Academy of Management Review, Vol. 26 (1), $117-127$

Murray, A, 1998, Minority Report on the company law review bill 1997, Parliamentary Joint Committee on Corporations and Securities, The Parliament of the Commonwealth of Australia, March

OECD, 2006, White Paper on Corporate Governance in Asia, Organization for Economic Co-operation and Development

Pettigrew, Andrew, 1992, On Studying Managerial Elites, Strategic Management Journal, Volume 13(2), 163-182

Pettigrew, A. M, 1979, On Studying Organizational Cultures, Administrative Science 
Quarterly, Vol. 24, 570-581

Pettigrew, A. M. 1997, What is Processual Analysis? Scandinavian Journal of Management, Vol. 13 No. 4 337-348

Redding G, 1993, The Spirit of Chinese Capitalism, Berlin, de Gruyter

Redding G and Wong G.Y.Y, 1986, The psychology of Chinese organizational behaviour, in M. H. Bond (ed), The psychology of the Chinese people, Hong Kong, Oxford University Press

Sachar, Nathan, 2010, Lula's Legacy, Prospect, October

Shakespeare, William, 1596/8, The Merchant of Venice, Act 1 Scene 1, first folio Smith, Adam, 1759, The Theory of Moral Sentiments

Smith, Adam, 1776, An Inquiry into The Wealth of Nations, Book V, page 439

Tricker, R. I, 1978, The Independent Director - a study of the non-executive director and audit committees, London, Tolley

Turnbull, Shann (2000), Why unitary boards are not best practice - a case for compound boards, First European Conference on Corporate Governance, Belgiasn Directors' Institute, November, Brussels Turnbull, Shann, 2002, Enhancing share price with superior investor protection. International Institute for Self-Governance, EFMA, London, pages 1-2 Wilson, Harold, 1976, The Governance of Britain, Wiedenfeld and Nicolson, London 


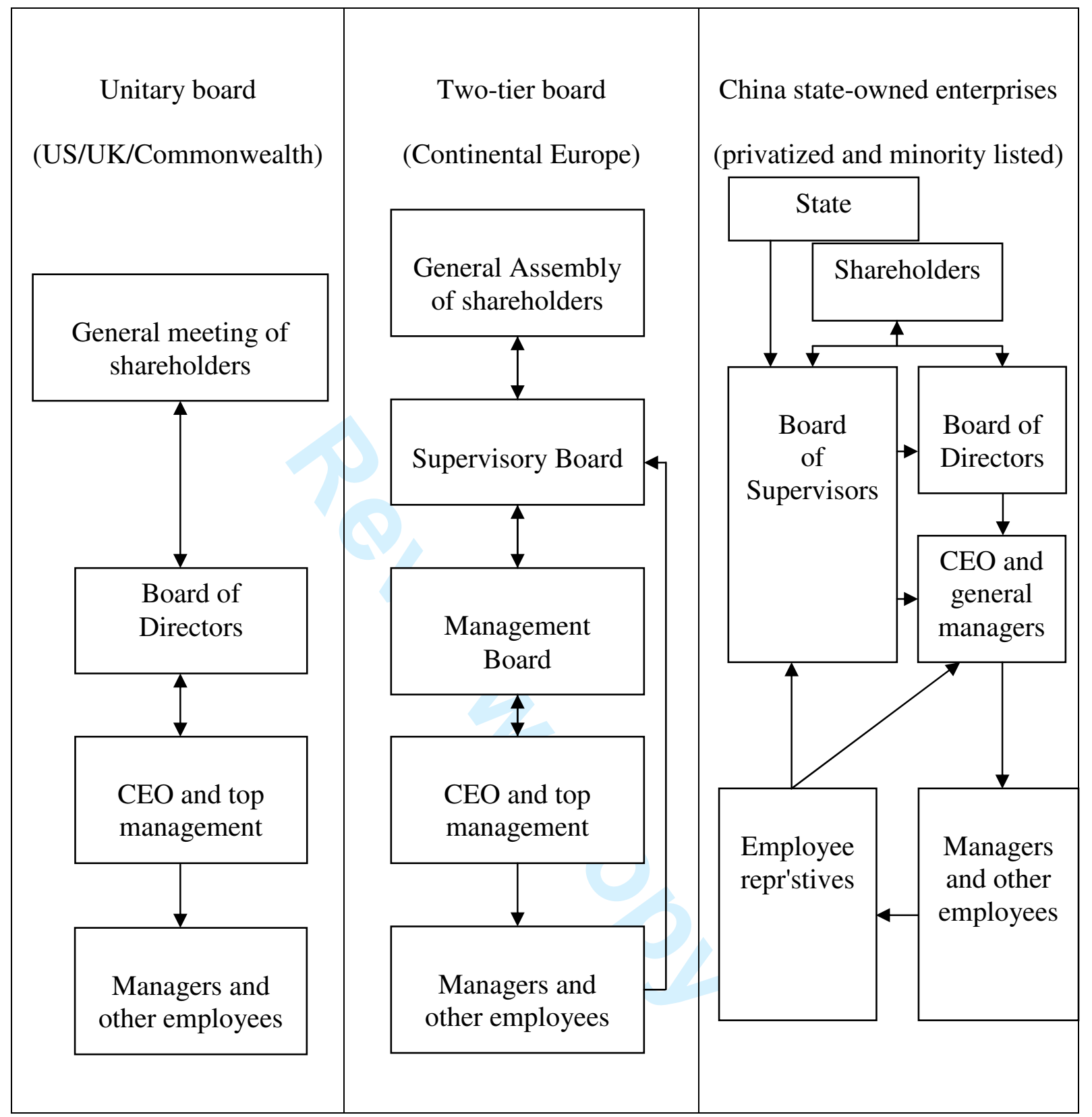

Figure 1 Models of corporate governance 


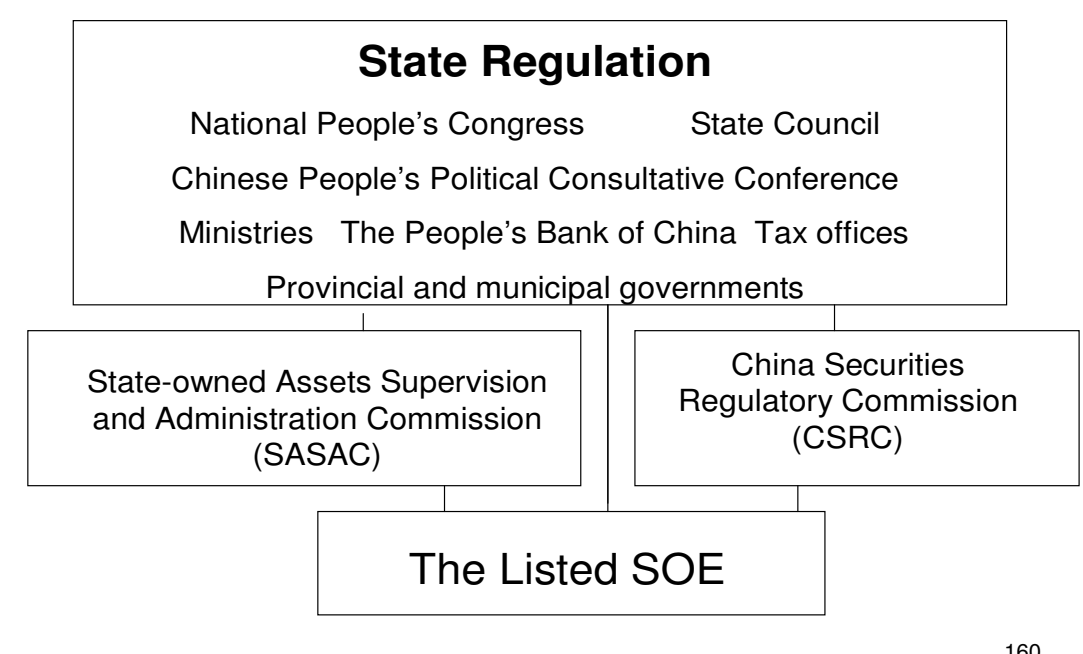

Figure 2 The regulation of China state-owned enterprises 
Equity shareholders, including institutional investors, individuals, sovereign funds, and state owners
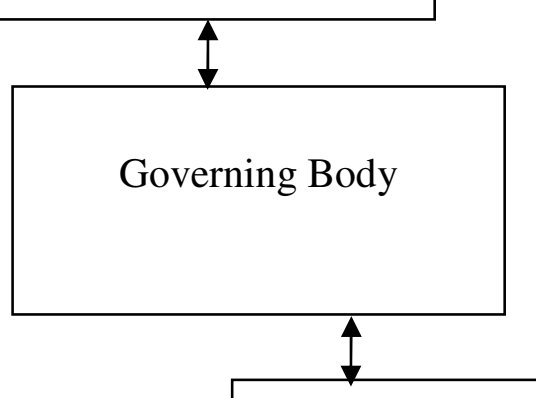

The Executive

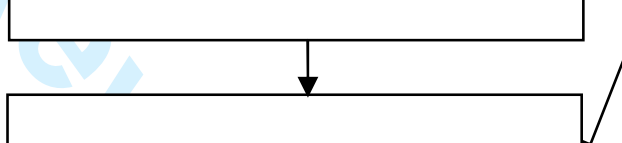

Managers and other employees
Stakeholders, including employees, customers, suppliers, other up and down stream contractors, and providers of non-equity finance

Stakeholder Liaison Groups

Figure 3 An alternative model of corporate governance 